\title{
Encephalitozoonosis in rabbits under different care conditions
}

\section{Farklı bakım koșullarındaki tavșanlarda encephalitozoonosis}

\author{
Hakan TÜFEK ${ }^{1}$, Özcan ÖZKAN²
}

\begin{abstract}
Objective: The aim of this study is to investigate the seroprevalence of Encephalitozoon cuniculi infection in rabbits in facilities with different care conditions in three different provinces.

Methods: The sera samples of rabbits that have been hosted in open, semi-open and controlled areas which were obtained from three different enterprises with different environmental possibilities, hygienic situations, maintenance and feeding conditions were evaluated by using the ELISA kits.

Results: Consequently, the seropositivity of the rabbits in open, semi-open and controlled shelters were found to be $70 \%, 40 \%$ and $80 \%$, respectively. In this study, in the rabbit under the different care conditions, antibodies anti - E. cuniculi $(63.3 \%)$ were found in all sera samples.

Conclusion: In the context of the data obtained, it was seen that the animals taken into the facility may be infected from the beginning and an infected animal in the facility may have been a source of infection for the many others in the facility. It was also concluded that the septic and aseptic rules which are potentially accepted in the facilties are not enough in battling with the agent and that the zoonotic disease can be a risk for animal keepers and researchers.
\end{abstract}

Key Words: Rabbit, Encephalitozoon cuniculi, serology, care conditions

\section{ÖZET}

Amaç: Bu çalıșmanın amacı farklı bakım ve hijyen koșullarına sahip tesislerde yetiștirilen tavşanlarda Encephalitozoon cuniculi'nin seroprevalansını araștırmaktır.

Yöntem: Farklı çevresel koșullara, hijyenik durumlara, bakım ve beslenme koșullarına sahip; açık, yarı açık ve kontrollü alanlarda barındırma yapılan üç farklı ișletmeden alınan tavșanların serum örnekleri ELISA kitleri kullanılarak değerlendirilmiștir.

Bulgular: Sonuç olarak, açık, yarı açık ve kontrollü barınaklardaki tavşanların seropozitifliği sırasıyla $\% 70, \% 40$ ve \%80 olarak bulunmuștur. Bu çalıșmada, farklı bakım koșullarına sahip üç tesise de serum örneklerinde anti - E. cuniculi (\%63.3) antikor varlığı tespit edilmiștir.

Sonuç: Elde edilen veriler ıșığında, tesise alınan hayvanların orijin olarak enfekte olabileceği, tesiste enfekte bir hayvanın sürü için enfeksiyon kaynağı olabileceği, tesislerde olası yürütülen septik/aseptik kuralların etkenle mücadele için yeterli olmadığı ve zoonoz karakterdeki enfeksiyonun hayvan bakıcısı ve araștırmacılar için de potansiyel risk tașıdığı kanısına varılmıștır.

Anahtar Kelimeler: Tavșan, Encephalitozoon cuniculi, seroloji, bakım koșulları

'Zonguldak Bülent Ecevit University, Çaycuma Vocational High School, Zonguldak

${ }^{2}$ Çankırı Karatekin University, Faculty of Science, Department of Biology, Çankırı

İletişim / Corresponding Author : Hakan TÜFEK

Zonguldak Bülent Ecevit Üni. Çaycuma Gida ve Tarım MYO 67900 Zonguldak - Türkiye

E-posta / E-mail : hakan.tufek@beun.edu.tr

DOI ID : 10.5505/TurkHijyen.2020.18784

Tüfek H, Özkan Ö. Encephalitozoonosis in rabbits under different care conditions

Turk Hij Den Biyol Derg, 2020; 77(3): 349-354 


\section{INTRODUCTION}

Encephalitozoon cuniculi is a eukaryotic, unicellular, compulsory intracellular living, sportive, monoxen, zoonotic, microsporidian parasite which can be found on many mammals, including rabbits, rodents, lagomorphs, carnivores, livestock, nonhuman primates, and humans (1-3).

The occurrence of infection in rabbits depends on the infective dose and the host resistance. Infection in rabbits generally occurs as asymptomatic and chronic. Signs of encephalitozoonosis may develop suddenly in rabbits, and severe cases may result in death. Evidence of vestibular disease, head tilt (bending the head-characteristic) and ataxia encephalitozoonosis are among the early findings (4-9).

The symptomatic or asymptomatic clinical picture is formed in rabbits' mouths (urine scattered in the cage-fecal contaminated food-water), by the inhalation or transplacental transmission of $E$. cuniculi spores which are resistant to environmental conditions and which can survive for 4-6 weeks (10, 11). Personnel who come into contact with animals should take into account the potential zoonotic risk, as infectious spores can be found in various body fluids, even if the animals are clinically healthy. Attention should be given to personal hygiene in order to prevent direct and indirect transmission by the fecal-oral route $(12,13)$. Therefore, before the rabbits' meat is eaten the laboratory animal or pet animal is taken into shelter and serological screening should be performed in case of disease. For this, animals that are seronegative should be used as a result of serological screening of samples taken every two weeks for two months $(12,14)$. Otherwise, it may cause loss of time and material resources besides zonotic risk. Improving the quality of care of the animals in the shelter, following the hygiene rules and carrying out periodic disinfection procedures, may help to keep the disease under control (12-14).

Santaniello et al. (15) emphasized that rabbits are the main reservoir of $E$. cuniculi and this parasite is important for public health. In addition, Shin et al. (16) reported that E. cuniculi, which is important in terms of zoonotic potential and public health, is present in and spreads through by domestic rabbits. In many studies, serological screening for $E$. cuniculi infection was advised, regardless of clinical evaluation in rabbits $(16,17)$.

In many facilities, which have various hygiene and care conditions in Turkey, encephalitozoonosis in rabbits have been reported histologically, serologically, clinically and molecular in several studies $(8,9,13,18-20)$. In this study, it was aimed to investigate the presence of $E$. cuniculi infection in rabbits in facilities with different care conditions in three different provinces.

\section{MATERIAL and METHOD}

\section{Animals, Care Condition and Clinical Evaluation}

The study was performed during the routine health evaluation which was executed under the responsibility of veterinarians. Blood samples taken from the rabbits in the relevant facilities for routine health screening were used in this study. The animals routine clinical checks such as daily water, feed intake, urine, fecal outputs were monitored and recorded. No experimental procedures have been performed on animals. Consequently, the study did not require an Animal Ethics statement in accordance with the Regulations (Article-2b) due to nonexperimental clinical veterinary medicine practices. In the study, the physical properties, environmental conditions and hygiene procedures of the three facilities located in Ankara, Istanbul and Tekirdag provinces were evaluated.

\section{Serological Analysis}

For routine clinical screening, blood samples were taken from the marginally used veins of the rabbits to the biochemistry gel tube. Blood samples were centrifuged at $2000 \mathrm{rpm}$ for 10 minutes. Serum samples were stored at $-20{ }^{\circ} \mathrm{C}$ until serological analysis was performed. An ELISA kit (Rabbit Biotech 
International-USA) containing positive and negative controls (rabbit serum) was used to determine $E$. cuniculi specific antibody (IgG) responses in rabbits. The analysis was carried out step by step according to the manufacturer's instructions. If the difference between sample optical density (OD) and negative control OD $(\Delta)$ was greater than or equal to 0.300 , the sample was considered positive.

\section{RESULTS}

The first study area was a shelter, an environment of which is created in an open area by the researcher, was limited by wire mesh and maintained in a wooden structure. There was no hygiene practice here and the animals were kept completely on the ground in groups. The animals were fully open to the environment and were fed with ordinary containers, feed, water and grass - vegetables. Natural lighting was used and there was not any air conditioning. Since this shelter was completely in traditional poultry structure, it (A) was defined as an uncontrolled shelter $(n=10)$.

The other study area was a semi-open shelter with no environmental control system, a shelter where air conditioning and lighting are uncontrolled, and it was a shelter where traditional family breeding was carried out through windows. This shelter (B) was defined as a semi-open shelter $(n=10)$. In this shelter, the animals $(n=46)$ were kept singly or in pairs within the wireframe. Commercial pellet feed water was provided to the animals.

The last workspace had a temperature of 18 to $21^{\circ} \mathrm{C}, 50 \pm 5 \%$ relative humidity, and a $12: 12$ light / dark cycle, with controlled environmental conditions, the working flow in accordance with the septic / aseptic rule, and a licensed shelter. This shelter (C) was defined as a controlled shelter $(n=10)$. The animals were kept in cages in accordance with the European standards, with one rabbit in each cage. Rabbits are fed with a standard commercial pellet feed and water and libitum is provided.

Adult rabbits of $2.0-3.5 \mathrm{~kg}$ body weight of the two gender were included in the study, while neurological findings such as torticollis, seizure, paralysis in the posterior and forelegs, fluttering in the eyes, cataract-like formations, strabismus, irregular vertical eye movements and normal clinical findings were observed in the evaluation of water, feed intake, urine, and fecal outputs of the subjects daily in terms of symptoms such as polydipsia, polyuria, and anamnesis.

In the serology analysis, a total of 30 rabbit sera, 10 from each shelter, were used. According to the ELISA results, the seropositivity of the animals in $A$ and $B$ shelters were found to be $70 \%(7 / 10)$, $40 \%(4 / 10)$ and $80 \%(8 / 10)$, respectively (Table 1$)$. The serologic results of the animals that have been bred in traditional pens with no hygiene rules (open system) and the ones that have been found bred in fully controlled systems were close to each other whereas the seropositivity in the semi-open system were lower. When evaluated regardless of shelter and hygiene characteristics, the rate of the disease was found to be $63.3 \%$ seropositive in rabbits (Table 1 ).

Table 1. The seropositivity of Encephalitozoon cuniculi in rabbits under different care conditions

\begin{tabular}{|c|c|c|c|c|c|c|}
\hline & \multicolumn{6}{|c|}{ CARE CONDITIONS } \\
\hline \multirow{2}{*}{ SHELTER } & \multicolumn{2}{|c|}{ UNCONTROLLED } & \multicolumn{2}{|c|}{ SEMI-OPEN } & \multicolumn{2}{|c|}{ CONTROLLED } \\
\hline & \multicolumn{2}{|c|}{$A(n=10)$} & \multicolumn{2}{|c|}{$B(n=10)$} & \multicolumn{2}{|c|}{$C(n=10)$} \\
\hline \multirow{2}{*}{ Encephalitozoon cuniculi } & + & - & + & - & + & - \\
\hline & 7 & 3 & 4 & 6 & 8 & 2 \\
\hline \multirow{2}{*}{ TOTAL (\%) } & \multicolumn{2}{|c|}{70} & \multicolumn{2}{|c|}{40} & \multicolumn{2}{|c|}{80} \\
\hline & \multicolumn{6}{|c|}{63.3} \\
\hline
\end{tabular}




\section{DISCUSSION}

Throughout history, animals which were the source of many transmissable diseases had an important role with regards to human health. Therefore, today, zoonoses is seen as a major public health problem, affecting all continents $(16,21$, 22). Infections caused by $E$. cuniculi in humans and animals have been reported in many continents of the World such as Asia, Europe, Africa and America (23-26). Consequently, and currently, the attention to E. cuniculi, which is important in terms of zoonotic potential and public health is increasing among the fields of veterinary medicine and human medicine.

In Northern Italy, a serological survey study on commercially reared rabbits reported a high prevalence of $E$. cuniculi infection (24). In another study, in 40 commercial rabbit farms, antibodies antiEncephalitozoon cuniculi were found in 505 of 1600 (75.4\%) sera samples (15). In the serological study conducted by Lavazza et al. (7), seropositivity was reported in 826 pet rabbits with and without clinical findings $(310 / 516)$ in $70.6 \%$ of sick rabbits and $52.9 \%$ of healthy rabbits. Serums collected from rabbits $(\mathrm{n}: 264)$ produced for meat in shelters with different ventilation systems using different managementnutrition programs in two different cities in Thailand were analyzed by ELISA test. The presence of anti- $E$. cuniculi IgG was $20 \%$ in one shelter and $71.9 \%$ in the other shelter (26). On the other hand, 300 clinically healthy rabbits and 300 people were investigated for $E$. cuniculi seropositivity in the shelters of different races in three cities with different climatic and environmental conditions in China. As a result of the study, respectively 6, 5, 18 and 9.67\% (29/300) people in different shelters in each region were found to be $18.67 \%(56 / 300)$ seropositive in total $(22)$. It has been reported that $63.5 \%$ of the serum samples of 337 rabbits with or without clinical findings, which were examined at the facility located in 20 different provinces in Japan, were found positive for anti-E. cuniculi IgG (27). In England, Scotland and Wales, serum obtained from 97 rabbits that did not show any clinical symptoms during routine health controls and pre-anesthesia controls which were analyzed by indirect ELISA method; 52 (53.6\%) samples were evaluated as $E$. cuniculi seropositive (28). In Brazil, Baldotto et al. (25) found $E$. cuniculi positivity rate as $85.0 \%(136 / 160)$ in asymptomatic animals and $61.5 \%(16 / 26)$ in diseased animals.

In this study, as a result of evaluating the samples taken from rabbits without any clinical symptoms, factors were found in all facilities at different locations and a percentage of 63.3 seropositivity was determined. In our study, seropositivity between 40 $80 \%$ was found in accordance with the previous studies which were conducted on the basis of provinces. As it is seen in our study and other studies, it was observed that the rate of the factor may change even in different places within the same country according to ecological indicators and cultivation systems. However, in the evaluation of the hygiene and care conditions of the shelters used in this study, the rate of seropositivity in the semi-open shelter system, which has no hygiene rule, was found to be lower compared to other shelters. On the other hand, the serological results of animals raised in unlicensed and controlled shelters with uncontrolled shelter system was found close to each other.

Regardless of the conditions of care, each animal newly taken into the facility should be considered to be infected from the beginning and should be quarantined. Serological screening should be done in this process. The facilities, cages and equipment should be disinfected at regular intervals. $E$. cuniculi spores are environmentally resistant, therefore environmental disinfection is important step for encephalitozoonosis control. There are a number of recommended disinfection protocols. Namely; 70\% ethanol, effectively kills the spores with a contact time of 30 seconds. Another protocol is also $0.1 \%$ bleach at a contact time of 10 minutes, on the other 
side, the different disinfection procedure is sodium hydroxide $(1 \%)$, formaldehyde $(0.3 \%)$ and hydrogen peroxide (1\%) effectively kill sports with contact time 30 minutes (29).

However, there were potential limitations according to the design of the study. Serological tests were not carried out before the animals were transported to their facility. The samples collected within the scope of clinical applications were collected from facilities that have different hygiene and care conditions and are currently active in their field. Therefore, its relatively common occurrence in the routine controlled facility selected for the study suggests that animals may become infected with $E$. cuniculi before being taken into the facility.

In the light of these results; (a) It should not be ignored that the animal circulation is not high and that even if it is a licensed shelter, the animals may be infected from the beginning when the animal was put to the shelter for the first time. (b) Serological screening of the animals should be integrated into the herd and the appropriate animals into the shelter at the end of the quarantine period. This is very important for herd health. (c) It should not be ignored that an infected animal in the shelter will be a source of infection for the herd, considering the transmission routes of the agent. (d) In the routine health screenings suggested by Federation of European Laboratory Animal Science Associations (FELASA), the animals identified as seropositive should be removed from the herd immediately. (d) Due to the high incidence of seropositivity in the shelters where standard protocols are applied, it is seen that septic/ aseptic application carried out in the shelters may not be sufficient to combat the factor due to spor form of the parasite being resistant to many environmental factors. (e) In terms of public health, it should be remembered that this infection of zoonotic character can be found in any shelter and can carry potential risk for animal keepers and researchers.

\section{TEŞEKKÜR}

This study was prepared from the master thesis by Hakan Tüfek in the Department of Biology, Institute of Natural and Appilied Science, ÇAKÜ.

\section{REFERENCES}

1. Didier ES, Weiss LM. Microsporidiosis: current status. Curr Opin Infect Dis. 2006; 19(5): 485-92.

2. Otto $\mathrm{GM}$, Franklin $\mathrm{CL}$, Clifford $\mathrm{CB}$. Biology and diseases of rats. In: Fox JG, Anderson LC, Otto GM, Pritchett-Corning KR, Whary MT, editors. American College of Laboratory Animal Medicine, Laboratory Animal Medicine (Third Edition). Boston: Academic Press; 2015. pp. 151-207.

3. Rodríguez-Tovar LE, Villarreal-Marroquín A, Nevárez-Garza AM, Castillo-Velázquez U, RodríguezRamírez HG, Navarro-Soto MC et al. Histochemical study of Encephalitozoon cuniculi spores in the kidneys of naturally infected New Zealand rabbits. J Vet Diagn Invest. 2017; 29 (3): 269-77. doi. org/10.1177/1040638716668559.
4. Jordan CN, Zajac AM, Lindsay DS. Encephalitozoon cuniculi infection in rabbits. Parasitology Compendium. 2006; 28 (2): 108-16.

5. Dipineto L, Rinaldi L, Santaniello A, Sensale $M$, Cuomo A, Calabria M et al.. Serological survey for antibodies to Encephalitozoon cuniculi in pet rabbits in Italy. Zoonoses Public Hlth. 2008; 55 (3): 173-5.

6. Weese JS, Fulford MB. Fungal Disease. In: Weese JS, Fulford MB, editors. Companion Animal Zoonoses. Ames, lowa, USA: Blackwell Publishing Ltd.; 2011. pp. 275-99.

7. Lavazza A, Chiari M, Nassuato C, Giardiello D, Tittarelli C, Grilli G. Serological investigation on Encephalitozoon cuniculi in pet rabbits in northcentral Italy. J Exot Pet Med. 2016; 25 (1): 52-9. 
8. Özkan Ö, Alçığır ME. Subacute Stage of Encephalitozoon cuniculi Infection in Eye Lesions of Rabbit in Turkey. Iran. J Parasitol. 2018; 13 (2): 301-9.

9. Ozkan O, Karagoz A, Kocak N. First molecular evidence of ocular transmission of Encephalitozoonosis during the intrauterine period in rabbits. Parasitol Int. 2019; 71: 1-4.

10. Rodríguez-Tovar LE, Nevárez-Garza AM, TrejoChávez A, Hernández-Martínez CA, Gustavo Hernández-Vidal G, Zarate-Ramos JJ et al. Encephalitozoon cuniculi: Grading the histological lesions in brain, kidney, and liver during primoinfection outbreak in rabbits. J Pathog. 2016; 1-9. doi.org/10.1155/2016/5768428.

11. Pellett S. Encephalitozoon cuniculi in rabbits: An overview. Companion Animal. 2016; 21 (5): 300-5. doi.org/10.12968/coan.2016.21.5.300.

12. Harcourt-Brown FM. Encephalitozoon cuniculi infection in rabbits. Semin Avian Exot Pet Med. 2004; 13 (2): 86-93.

13. Ozkan O, Ozkan AT, Zafer K. Encephalitozoonosis in New Zealand rabbits and potential transmission risk. Vet Parasitol. 2011; 179 (1-3): 234-7. doi. org/10.1016/j.vetpar.2011.02.007.

14. Keeble E. Nervous system and musculoskeletal disorders. In: Meredith A and Lord B, editors. BSAVA Manual of Rabbit Medicine, England: British Small Animal Veterinary Association; 2016. pp: 214-32.

15. Santaniello A, Dipineto L, Rinaldi L, Menna LF, Cringoli G, Fioretti A. Serological survey of Encephalitozoon cuniculi in farm rabbits in Italy. Res Vet Sci. 2009; 87: 67-9.

16. Shin JC, Kim DG, Kim SH, Kim S, Song KH. Seroprevalence of Encephalitozoon cuniculi in pet rabbits in Korea. Korean J Parasitol. 2014;52(3):3213. doi.org/10.3347/kjp.2014.52.3.321.

17. Künzel F, Fisher PG. Clinical signs, diagnosis, and treatment of Encephalitozoon cuniculi infection in rabbits. Vet Clin North Am Exot Anim Pract. 2018; 21 (1): 69-82. doi:10.1016/j.cvex.2017.08.002. PMID:29146032.

18. Berkin Ș, Kahraman MM. Türkiye'de tavșanlarda Encephalitozoon (Nosema) cuniculi enfeksiyonu. Ankara Univ Vet Fak Derg. 1983; 30 (2): 397-406.
19. Eröksüz H, Eröksüz Y, Metin N, Özer H. Morphologic examinations of cases of naturally acquired encephalitozoonosis in a rabbit colony. Turk J Vet Anim Sci. 1999; 23: 191-5.

20. Eröksüz $Y$, Eröksüz H, Özer H, Cevik A, Unver 0 . A survey of Encephalitozoon cuniculi infection in rabbit colonies in Elazig, Turkey: Pathomorphologic and serologic (Carbonimmunoassay Test) studies. Isr J Vet Med. 1999a; 54 (3): 73-7.

21. Kruse H, Kirkemo A, Handeland K. Wildlife as source of zoonotic infections. Emerg Infect Dis. 2004; 10 (12): 2067-72. doi:10.3201/eid1012.040707.

22. Pan Y, Wang S, Liu X, Li T, Sun Y, Gadahi JA. Seroprevalence of Encephalitozoon cuniculi in humans and rabbits in China. Iran J Parasitol. 2015; 10 (2): $290-5$.

23. Okewole EA. Seroprevalence of antibodies to Encephalitozoon cuniculi in domestic rabbits in Nigeria. Onderstepoort J Vet. 2008; 75 (1): 33-8.

24. Lonardi C, Grilli G, Ferrazzi V, Cin MD, Rigolin D, Piccirillo A. Serological survey of Encephalitozoon cuniculi infection in commercially reared rabbit does in Northern Italy. Res Vet Sci. 2013; 94: 295-8.

25. Baldotto SB, Cray C, Giannico AT, Reifur L, MontianiFerreira F. Seroprevalence of Encephalitozoon cuniculi infection in pet rabbits in Brazil. J Exot Pet Med. 2015; 24 (4): 435-40.

26. Intachat C, Jiwaganont $P$, Wannasilp $S$, Udompattanakorn $\mathrm{O}$, Kovitvadhi, Jala $\mathrm{S}$ et al. Slaughterhouse seroprevalence of Encephalitozoon cuniculi in meat rabbits at central part of Thailand. Thai J Vet Med. 2018; 12 (2): 35-45.

27. Igarashi M, Oohashi E, Dautu G, Ueno A, Kariya T, Koji F. High seroprevalence of Encephalitozoon cuniculi in pet rabbits in Japan. J Vet Med Sci. 2008; 70 (12): 1301-4.

28. Keeble EJ, Shaw DJ. Seroprevalence of antibodies to Encephalitozoon cuniculi in domestic rabbits in the United Kingdom. Vet Rec. 2006; 158 (16): $539-44$.

29. Jordan CN, Dicristina JA, Lindsay DS. Activity of bleach, ethanol and two commercial disinfectants against spores of Encephalitozoon cuniculi. Vet Parasitol. 2006; 136 (3-4):343-6. 